\title{
Processing of Vanadium-containing Converter Slag to Produce Higher-purity Vanadium Pentoxide
}

\section{Boris Dmitrievich Khalezov and Alexey Gennadyevich Krasheninin}

Institute of Metallurgy UB RAS, Yekaterinburg, Russia

\section{Abstract}

Russia is one of the world leaders known for its reserves of vanadium that forms titanomagnetite ores. Vanadium-containing manganic slags from titanomagnetite smelting produced by PJSC EVRAZ NTMK are used as raw materials to produce vanadium compounds. In our country these slags are only used to produce vanadium concentrate (technically pure vanadium pentoxide with the content of the main substance 80-90\%) for vanadium iron production. Manganese, which is also a part of the slags, is not extracted. At the same time, domestic requirements of pure vanadium pentoxide and manganese oxides are satisfied by importing them from abroad. In the Institute of Metallurgy (Ural Branch, Russian Academy of Sciences) a new integrated ecologically clean technology has been developed to process vanadium-containing manganic metallurgical slags and to obtain pure vanadium pentoxide and manganese oxides. The technology includes oxidative roasting of manganic vanadium slags at $\mathrm{T}=850^{\circ} \mathrm{C}$ without any calcium- or sodium-containing additives in contrast to the existing technologies and leaching vanadium out of cinder by aqueous solutions of soda ash on the first stage, and leaching manganese out of vanadium-containing residues formed on the first stage by sulfuric acid solutions on the second stage. The obtained vanadium pentoxide and manganese oxides are good to utilize for melting vanadiumand manganese-containing addition alloys for titanium and aluminum alloys. Hard residues are utilized to manufacture ferroalloys and to use in construction industry. The authors of the present work propose to consider the possibility to realize the technology in a factory manufacturing vanadium slag.

Keywords: converter slag, pure vanadium pentoxide, manganese, aggregate raw material processing

\section{Introduction}

The main source of vanadium in Russia is titanomagnetite ores occurring at Kachkanar (Urals), Chineyskoe and Kurnakhskoe (Siberia) deposits. In the recent times, in the Nizhny Tagil metallurgical plant (PJSC EVRAZ NTMK) titanomagnetite vanadiumcontaining ores of the Kachkanar deposits are processed by using blast-furnace smelt- 


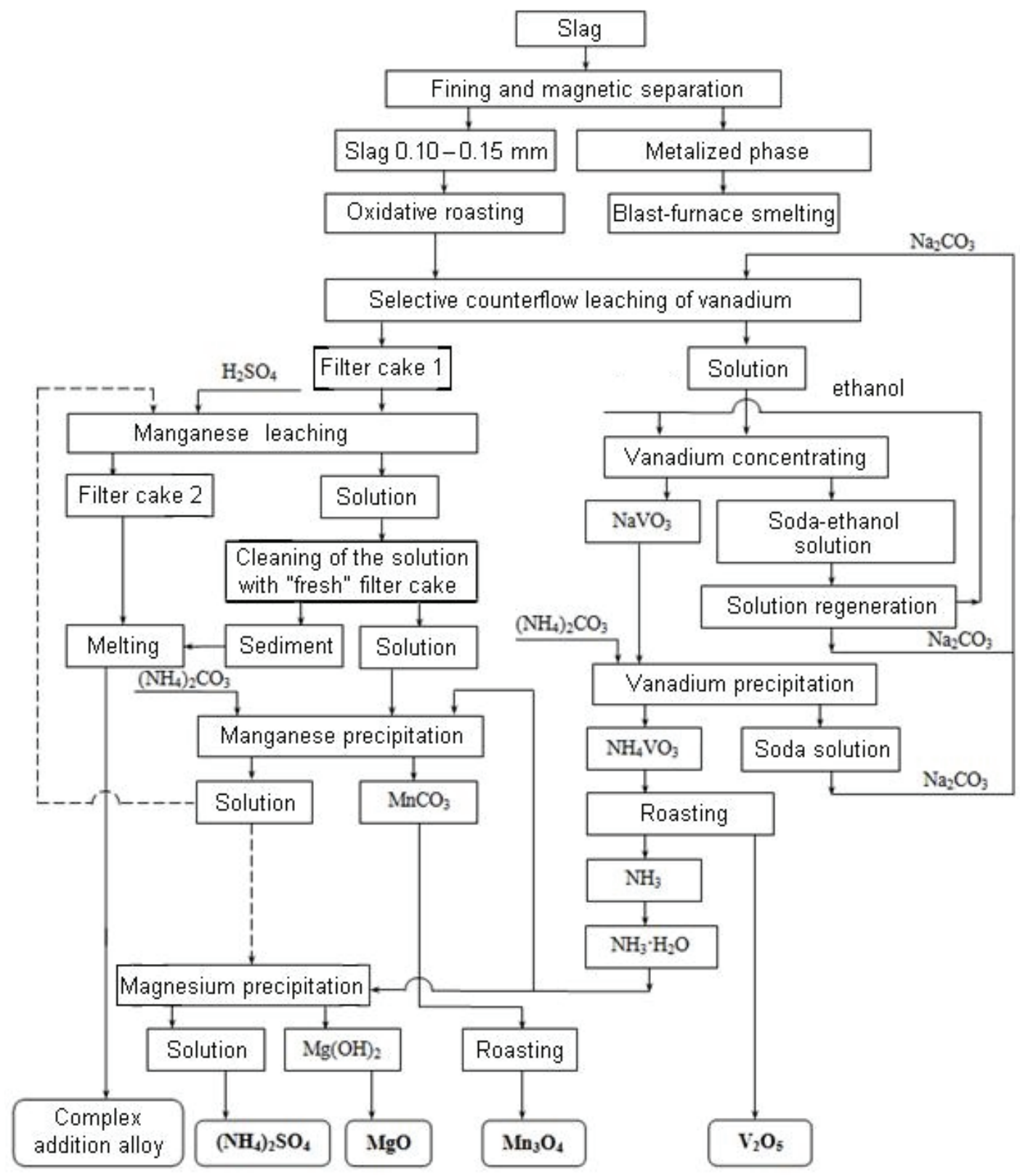

Figure 1: A principled flowsheet of the aggregate processing of the manganic vanadium slags.

ing. As a result, steel and converter slags are obtained containing $\mathrm{V}_{2} \mathrm{O}_{5}$ in a concentration up to $25 \%$ by mass [1]. Annually, in the NTMK such slags are produced in a quantity of 120 thousand tons containing 30 thousand tons of vanadium. 40 thousand tons are processed by PJSC EVRAZ Vanadium (The city of Tula) and 10 to 15 thousand tons - by Chusovskoy Metallurgical Plant. The other 70 metric tons of the slag containing vanadium are sold abroad. In the domestic enterprises (PJSC EVRAZ Vanadium, Tula and OJSC "Chusovskoy Metallurgical Plant") a concentrate containing 80-90 mass \% of $\mathrm{V}_{2} \mathrm{O}_{5}$ is used to melt vanadium iron [2]. Pure vanadium pentoxide ( $\geq 99.5 \mathrm{wt}$. \% 
$\mathrm{V}_{2} \mathrm{O}_{5}$ ) is not produced in Russia but purchased abroad. In 2016 in the NTMK a crushing and grinding system was developed for fining and magnetic separating of vanadium slag. The system performance is 135 thousand tons per year, and that was enough to abandon the services of intermediaries [3]. This is the main operation of the slag processing technology.

It is proposed to build a slag processing shop with a performance of 70 metric ton per year in Kushva (a town placed $40 \mathrm{~km}$ from the NTMK) with use of the new technology developed by the institute of Metallurgy. The technology provides obtaining not vanadium concentrate but pure vanadium pentoxide. The point is the requirements of the domestic titanium enterprise PJSC “VSMPO-AVISMA Corporation” (V.Salda, Sverdlovsk region) for pure $\mathrm{V}_{2} \mathrm{O}_{5}$ is 1.5 thousand tons per year in the recent times and may reach as much as 3.5 thousand tons per year in the future. Moreover, pure vanadium pentoxide is needed for other industry branches such as oil-refining and chemical ones, and also to produce a number of special alloys.

The technology of IMET UB RAS provides not only obtaining pure $\mathrm{V}_{2} \mathrm{O}_{5}$ but also manganese oxides and complex addition alloys from the filter cake obtained during slag processing (Figure 1). The first step of the technology includes oxidative roasting of the slag at $850^{\circ} \mathrm{C}$ without any calcium or sodium additions, which are usually used in the existing technologies, in obtaining soluble manganese vanadate $\left(\mathrm{Mn}_{2} \mathrm{~V}_{2} \mathrm{O}_{7}\right.$, $\mathrm{MnV}_{2} \mathrm{O}_{6}$ ). In the second step, vanadium undergoes selective soda leaching to obtain a solution of sodium vanadate $\left(\mathrm{NaVO}_{3}, \mathrm{Na}_{3} \mathrm{VO}_{4}\right)$, and further the solution is treated with ammonium carbonate $\left(\mathrm{NH}_{4}\right)_{2} \mathrm{CO}_{3}$ to precipitate ammonium vanadate $\mathrm{NH}_{4} \mathrm{VO}_{3}$. After that, the ammonium vanadate undergoes roasting in obtaining pure $\mathrm{V}_{2} \mathrm{O}_{5}$ which satisfies the requirements of the technical specification 48-4-429-82 for alloying titanium and aluminum alloys and other needs. In the next step, manganese is leached in obtaining manganese oxide $\mathrm{Mn}_{3} \mathrm{O}_{4}$. Finally, filter cakes obtained after leaching vanadium and manganese are utilized to melt complex addition alloys. It is significant that all process waters are recycled in the technological scheme [4].

Thus, the technology is aggregate and ecologically clean without air and water pollutions and without land alienation to manage solid wastes.

A practical application of the technology in the way of import substitution policy would allow eliminating the dependence of Russia on import of pure vanadium pentoxide. 


\section{References}

[1] Smirnov, L.A. (2007). Expansion of production and vanadium application for steel microalloying, in Materials of International scientific and technical workshop. Yekaterinburg: UB RAS.

[2] Smirnov, L.A., et al. (1985). Production with use of vanadium slags. Moscow: Metallurgy.

[3] News agency "Mezhdu strok". (2016). A unique production has been opened in Nizhniy Tagil, Mezhdu strok, May 23, https://mstrok.ru/news/v-nizhnem-tagileotkrylos-unikalnoe-dlya-rossii-proizvodstvo.html

[4] Khalezov, B.D., et al. (2016). Processing of converter manganic vanadium slags. Yekaterinburg: EPD UB RAS. 